\title{
Fluorometric assay of the protein content of mouse and rat embryos during preimplantation development*
}

\author{
J. Schiffner and H. Spielmann \\ Abteilung Embryonal-Pharmakologie, Department of Pharmacology, Freie Universität Berlin, \\ 1 Berlin 33, Thielallee 69/73, West Germany
}

Quantitative and qualitative aspects of protein synthesis during the preimplantation development of the mouse have been studied by several groups (Weitlauf \& Greenwald, 1967; Brinster, 1971; Epstein \& Smith, 1973, 1974). Because of methodological difficulties, however, little attention has been given to the problem of estimating the absolute amounts of protein found in mouse embryos at successive stages of development. The protein content of embryos from mice induced to superovulate has been determined for the first 5 days of development by a micro-Lowry technique (Brinster, 1967). The protein content decreased from $28 \mathrm{ng}$ at the 1-celled stage to $20.5 \mathrm{ng}$ at the morula stage, and there appeared to be a $15 \%$ increase in total protein when the blastocyst was formed ( $23 \mathrm{ng}$ ). Using the same technique, Weitlauf (1973) reported a net increase of $52 \%$ (23 to $35 \mathrm{ng}$ ) of the protein content of mouse blastocysts during a 10-hr period just before implantation. Measurements of dry weight during the same period confirmed these results (Hensleigh \& Weitlauf, 1974). Since the protein content of preimplantation mouse embryos is very small, such determinations have been carried out on considerable numbers of embryos. There are no comparable reports on preimplantation rat embryos. We have therefore studied changes in the protein content of preimplantation mouse and rat embryos by the sensitive and simple fluorometric assay of proteins with fluorescamine (Udenfriend et al., 1972; Böhlen, Stein, Dairman \& Udenfriend, 1973).

Female mice of the NMRI strain weighing $30 \mathrm{~g}$ (Schwenke \& Co., Nauheim, Germany) and Wistar SW 72 rats weighing $200 \mathrm{~g}$ (Winkelmann, Kirchborchen, Germany) were bred under a normal day/night cycle and placed with males overnight. Embryos were obtained at the following times after the midpoint of the dark period: 1-celled stage of mice and rats, $12 \mathrm{hr}$; 2-celled stage of mice and rats, $36 \mathrm{hr}$; 8-celled stage of mice, $60 \mathrm{hr}$ and rats, $84 \mathrm{hr}$; morulae and early blastocysts of mice, $84 \mathrm{hr}$ and rats, $108 \mathrm{hr}$; late blastocysts of mice, $96 \mathrm{hr}$ and rats, $120 \mathrm{hr}$. Implantation occurs between 96 and $108 \mathrm{hr}$ in the mouse and between 120 and $132 \mathrm{hr}$ in the rat. All media and solutions were prepared from three times quartz-distilled water. Handling and washing of the embryos were performed by the method of Brinster (1967) in a phosphate-buffered Krebs-Ringer solution, pH 7·2, containing $0.1 \%$ Ficoll (Sigma Co., Munich, Germany). Cumulus cells were removed from zygotes with 150 units (mice) or 400 units (rats) hyaluronidase (Boehringer, Mannheim, Germany)/ml medium. From the third washing solution embryos were allocated to groups of $30-45$ and picked up in a volume of $5 \mu$ land placed in Eppendorf microtest-tubes (Eppendorf GmbH, Hamburg, Germany). Samples $(5 \mu \mathrm{l})$ of the last washing medium served as blanks. Embryos and blanks were stored frozen at $-40^{\circ} \mathrm{C}$ in the microtest-tubes. Hydrolysis of the samples was achieved by addition of $10 \mu \mathrm{l} 5 \mathrm{~N}-\mathrm{HCl}$ after incubation with $5 \mu 110 \mathrm{~N}-\mathrm{NaOH}$ at $56^{\circ} \mathrm{C}$ for $30 \mathrm{~min}$. The fluorescamine method for protein determination was as described by Böhlen et al. (1973); $300 \mu 10.2 \mathrm{M}$-borate buffer, $\mathrm{pH}$ 9.0 , and $100 \mu \mathrm{l}$ of a solution of $30 \mathrm{mg}$ fluorescamine (Fluram: Roche, Basel, Switzerland) $/ 100 \mathrm{ml}$ acetone (fluorescence-spectroscopy grade: Merck A.G., Darmstadt, Germany) were added to the sample while the microtest-tubes were held on a vortex mixer for $5 \mathrm{sec}$. Fluorescence was measured $30 \mathrm{sec}$ later in microcuvettes (Zeiss) with a spectrofluorometer (ZFM 4C: Carl Zeiss A.G. Oberkochen, Germany); the excitation wavelength was set at $390 \mathrm{~nm}$ and the emission wavelength at $482.5 \mathrm{~nm}$. The fluorescence values of the blanks were subtracted from the fluorescence values of the samples. The corrected values and a standard calibration curve of bovine serum albumin (Fraction V: Sigma), which had been hydrolysed in the same manner with each replicate, were used to deter-

\footnotetext{
* Reprint requests to Dr H. Spielmann.
} 
mine the amounts of protein in the embryos. According to our standard curve the average correlation coefficient, $r$ ( $r=$ relative units of fluorescence/mg total protein in the assay) was 0.15 for protein values between 0.5 and $1.5 \mathrm{mg}$, the amounts commonly used in our determinations. To compare changes in protein content with changes in the number of cells/embryo, nuclei in morulae and blastocysts were stained and counted by the method of Tarkowski (1966).

Table 1. The mean ( \pm S.D.) number of cells and protein content during the normal preimplantation development of mouse and rat embryos (no. of replicates in parentheses)

\begin{tabular}{|c|c|c|c|c|}
\hline \multirow[b]{2}{*}{ Developmental stage } & \multicolumn{2}{|c|}{ Mouse } & \multicolumn{2}{|c|}{ Rat } \\
\hline & No. of cells/embryo & $\begin{array}{l}\text { Protein content/ } \\
\text { embryo (ng) }\end{array}$ & No. of cells/embryo & $\begin{array}{l}\text { Protein content/ } \\
\text { embryo (ng) }\end{array}$ \\
\hline $1-$ cell & 1 & $24 \cdot 5 \pm 6 \cdot 5(8)$ & 1 & $36 \cdot 6 \pm 4 \cdot 6(5)$ \\
\hline 2-cell & 2 & $26.2 \pm 6.6(5)$ & 2 & $32 \cdot 5 \pm 4 \cdot 3(10)$ \\
\hline 8-cell & 8 & $22 \cdot 0 \pm 5 \cdot 5(5)$ & 8 & $32 \cdot 8 \pm 5 \cdot 2(5)$ \\
\hline Morula & $25.9 \pm 4.8(18)$ & $20 \cdot 9 \pm 5 \cdot 0(5)$ & $14 \cdot 6 \pm 4 \cdot 2(10)^{* * *}$ & $29 \cdot 0 \pm 4 \cdot 1(5)$ \\
\hline Early blastocyst & $34 \cdot 5 \pm 4 \cdot 0(15)$ & $24 \cdot 8 \pm 6 \cdot 2(10)$ & $29.6 \pm 6.6(28)$ & $27 \cdot 7 \pm 4 \cdot 5(13)$ \\
\hline Late blastocyst* & $85.9 \pm 16 \cdot 0(22)$ & $40.8 \pm 8.4(7)^{* *}$ & $46 \cdot 0 \pm 5 \cdot 1(24)^{* * * *}$ & $26.8 \pm 5.6(9)^{* * * *}$ \\
\hline
\end{tabular}

* Hatched and unhatched blastocysts.

** Significantly higher than for other protein values of the mouse, $P<0.001$.

*** Significantly lower than the comparable stage for the mouse, $P<0.001$.

The results are shown in Table 1. In the mouse the absolute values are comparable to those of Brinster (1967) and Hensleigh \& Weitlauf (1974). The daily changes of total protein were not statistically significant, but the increase of $65 \%$ from the early to the late blastocyst stage was significant $(P<0.001)$. There were no significant differences in cell number and protein content between late blastocysts with zona pellucida intact and those without the zona after hatching. A $52 \%$ increase in protein and a $84 \%$ increase in dry weight were reported between the early and the late blastocyst stage by Weitlauf (1973) and Hensleigh \& Weitlauf (1974). The changes between consecutive developmental stages in the rat were not significantly different and there was no increase in protein content before implantation. The total protein of late blastocysts of rats was significantly lower $(65 \%$; $P<0.001)$ than that of late blastocysts of mice. The cell number/embryo was significantly lower $(P<0.001)$ at the morula and the late blastocyst stage $(55 \%)$ in the rat than in the mouse. The amount of protein/cell decreased during the preimplantation period; it was nearly equal at the late blastocyst stage for the two species even though the mouse embryos have nearly twice the cell number.

The increase in cell number and protein content of mouse embryos reported in this and earlier papers is concurrent with the trophoblast giant cell transformation (Dickson, 1969). Since the late blastocysts were collected at the beginning of a 12-hr implantation period for both species, the developmental stages were expected to be comparable. As the rat embryos do not increase in cell number and protein at this stage, giant cell transformation in rat blastocysts may begin later or progress more slowly than in mouse blastocysts.

In a further experiment, we measured the cell number and protein content of mouse embryos cultured for $48 \mathrm{hr}$ from the 8-celled to the blastocyst stage according to the method of Brinster (1963). Blastocysts which had developed in Brinster's medium containing $0 \cdot 3 \%$ bovine serum albumin had a cell number of $81 \pm 21$ (S.D.) (35 determinations) and a protein content of $36 \pm 5.0 \mathrm{ng}$ ( 5 determinations), values similar to those for normal late blastocysts (Table 1). In other determinations we obtained identical values of total protein for zygotes from normally ovulating (Table 1) and superovulating mice (26.6 $\pm 8.7 \mathrm{ng} ; 7$ determinations). These results, when compared with the protein determinations of embryos from mice induced to superovulate (Brinster, 1967) and the data of Weitlauf (1973), show that there are no substantial differences between the early embryos of mice ovulating normally or superovulating. 
This investigation was part of the Dr med. thesis of J.S.; it was supported by grants from the Deutsche Forschungsgemeinschaft given to the Sonderforschungsbereich 29 "Embryonale Differenzierung und Entwicklung".

\section{References}

Böhlen, P., Stein, S., Dairman, W. \& Udenfriend, S. (1973) Fluorometric assay of proteins in the nanogram range. Archs Biochem. Biophys. 155, 213220.

BRINSTER, R.L. (1963) A method for in vitro cultivation of mouse ova from two-cell to blastocyst. Expl Cell Res. 32, 205-208.

BRINSTER, R.L. (1967) Protein content of the mouse embryo during the first 5 days of development. J. Reprod. Fert. 13, 413-420.

BRINSTER, R.L. (1971) Uptake and incorporation of amino acids by the preimplantation mouse embryo. J. Reprod. Fert. 27, 329-338.

Dickson, A.D. (1969) Cytoplasmic changes during the trophoblastic giant cell transformation of blastocysts from normal and ovariectomized mice. J. Anat. 105, 371-380.

Epstein, C.J. \& Smith, S. (1973) Amino acid uptake and protein synthesis in preimplantation mouse embryos. Devl Biol. 33, 171-184.

EPSTEIN, C.J. \& SMITH, S. (1974) Electrophoretic analysis of proteins synthesized by preimplantation mouse embryos. Devl Biol. 40, 233-244.

Hensleigh, H.C. \& Weitlauf, H.M. (1974) Effect of delayed implantation on dry weight and lipid content of mouse blastocysts. Biol. Reprod. 10, 315-320.

TARKowSkI, A.K. (1966) An air-drying method for chromosome preparations from mouse eggs. Cytogenetics 5, 394-400.

Weitlauf, H.M. (1973) Changes in the protein content of blastocysts from normal and delayed implanting mice. Anat. Rec. 176, 121-123.

Weitlauf, H.M. \& Greenwald, G.S. (1967) A comparison of the in vivo incorporation of $\mathrm{S}^{35}$-methionine by two-celled mouse eggs and blastocysts. Anat. Rec. 159, 249-254.

Udenfriend, S., Stein, S., Böhlen, P., Dairman, W., Leimgruber, W. \& Weigele, M. (1972) Fluorescamine: a reagent for assay of amino acids, peptides, proteins, and primary amines in the picomole range. Science, N. Y. 178, 871-872.

Received 17 November 1975 